\title{
KITEKINTŐ
}

\section{TERÜLETFEJLESZTÉS NÉMETORSZÁGBAN}

\author{
(Regional Development in Germany)
}

\author{
TATAI ZOLTÁN
}

Az ősz folyamán két hetet tölthettem Németországban vendégként. Sokat utaztam és igyekeztem tapasztalatokat gyủjteni, ebből kívánok most egy keveset átadni, elsősorban a területfejlesztéssel kapcsolatban.

Németországban, mindenekelött a korábbi NDK területén a területfejlesztés talán legfontosabb, de mindenesetre leglátványosabb megnyilvánulása a települések közelében, a beépített területek szomszédsági körzeteiben a területek közösségi célra történő elöközmüvesítése. Ez a nagyvárosok (Drezda, Lipcse, Magdeburg) és kisebb városok, nagyobb falvak térségében egyaránt látható, természetesen a méretek lényegesen eltérỏek. Úgy látszik a települések vezetői, illetve a tervezö-beruházó szervezetek, vállalkozók a zöldmezös fejlesztéseket, a települések melletti szabad mezőgazdasági területeken a tervszerü területelökészítést, az előközmúvesítést tartják leginkább célravezetőnek a modern, korszerü gazdaságfejlesztés megfelelö keretének.

A volt NDK iparának kapacitása felerészben sincs kihasználva, nincs túlzott igény az NDK időszakában épített ipari kapacitások iránt. A mindenfelé folyó területelökészitő munkálatokból és a beruházási támogatásokból úgy tűnik, hogy nem a korábban épült üzemek korszerúsítésére, inkább a zöldmezős telepítésü ủj üzemekre alapozzák a keletnémet ipar megújítását.

A tervszerü területelökészítés, az elöközmüvesítés, a gazdaságfejlesztés e módszerének bemutatására egy nagyobb létesítményt viszonylag részletesen, néhány kisebb fejlesztést érintőlegesen kívánok ismertetni.

\section{Technológiai Park Ostfalen (TPO)}

Magdeburgtól északnyugatra, a városi agglomerációhoz tartozó Ostfalen falu határában technológiai parknak nevezett területelőkészítő munka folyik. A beruházás méreteire jellemző, hogy mintegy 1300 hektár nagyságú terület elökészítéséről van szó, ahol magas müszaki kultúrát képviselö ipari tevékenységnek kívánnak helyet biztositani. 
A beruházás megvalósításának megszervezésére a térség települései és két járás önkormányzata célfejlesztési társaságot hozott létre. A társaság a fejlesztésre kiszemelt területet megvásárolta, az alapközmüvesítést (víz- és csatornahálózat, villamosenergia-hálózat), útépitést, kommunikációs rendszerek kiépítését, tereprendezést és fásítást elvégeztette. Az egész területet a várható igényeknek, illetve az elöterveknek megfelelöen felparcellázták, szekciókra osztották és áruba bocsátották, illetve folyamatosan eladják. A technológiai park terveit a Magdeburgi Tervező Vállalat dolgozta ki.

A Magdeburg térségébe telepített Technologiepark Ostfalen (a kiadványokban TPOnak rövidítve) beruházásnak alapvetöen három feladata van:

- ipari üzemek letelepítésének elösegitésére közmüvesített ipari terület elökészitése;

- az ipari termelést és a lakosságot kiszolgáló tevékenységek számára közmüvesitett terület kialakítása;

- a technológiai fejlesztések elősegítésére, a kisebb vállalkozások támogatására „inkubátorház" építése.

A technológiai park létrehozását Sachsen-Anhalt tartomány kormánya támogatja, mivel várhatóan, jelentős szerepe lesz a térség gazdasági fellendítésében, mert elősegíti:

- az innováció fejlődését, a magasabb szintủ termelötevékenység meghonosítását és kiterjesztését;

- új munkahelyek létrehozását és ezzel együtt a munkanélküliség csökkentését (a technológiai park teljes kiépülésével, illetve betelepülésével mintegy 10000 új munkahely létrejöttével számolnak);

- az új vállalkozói réteg kialakulását, az ipari-szellemi alkotók vállalkozási próbálkozásához a technikai háttér biztosítását;

- az elönyös földrajzi adottságok és beruházási feltételek folytán más országrészekböl és kưllföldröl a töke vonzását.

A kormányzat a fejlesztési költségekhez 70\%-os dotációt biztosít. A beruházás szervezésével foglalkozó intézménynek jó a kapcsolata a tartományi szervekkel, amit az is jelez, hogy vezetöje egyben a tartományi vállalati kamara elnöke.

A kiemelkedő méretủ technológiai park Magdeburg térségébe való telepitését történelmi, társadalmi és földrajzi adottságok egyaránt indokolják. Magdeburg az újraegyesítés utáni közigazgatási átrendezés révén Sachsen-Anhalt tartomány fỏvárosa lett. Földrajzi helyzetéből adódóan az észak-déli és kelet-nyugati irányú közlekedésben és kereskedelemben hosszú évszázadok óta jelentős szerepe volt. A két országrész egyesítése potenciálisan megváltoztatta Magdeburg és környéke helyzetét. A korábban is fejlett gépipar továbbfejlesztéséhez a rendelkezésre álló szakképzett munkaerő kedvező feltételt nyújt, ami a nyugati országrészből várható tőke és technológia fogadására a térséget alkalmassá teszi. A volt NDK területén ugyanakkor a barnakőszén-bányászat hanyatlása a kiszolgáló gépipart (ennek egyik központja Magdeburg és a közeli Köthen) is visszavetette, a felszabadult munkaerö lekötése égetöen szükséges, mert megindult az elvándorlás különösen a fiatalok körében. A közeli térségekben megszünt a rézércbányászat, rézkohá- 
szat és feldolgozás, csökkent a vegyipari, visszaesett a mezögazdasági termelés, ami Magdeburgon túl térségi problémává emelte a munkanélküliséget.

A technológiai park helyének kiválasztása kedvező, amelyet az 1. ábra jól szemléltet.

\section{1. ÁBRA}

A Technológiai Park Ostfalen telepítési vázlata

(Location draft of Technological park Ostfalen)

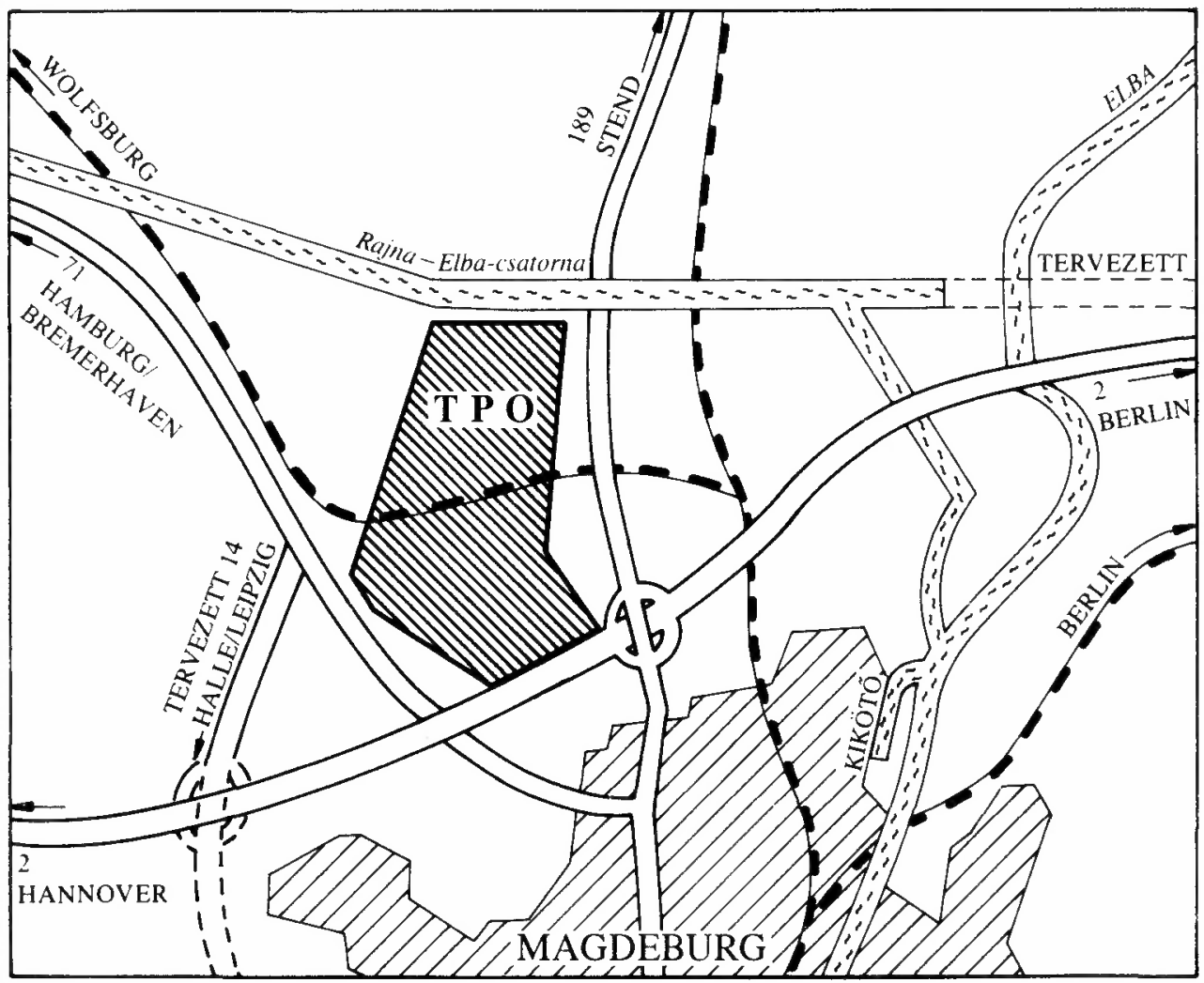

A kiválasztott terület Magdeburg szélétől mintegy tíz km-re található, tehát elég közel a közvetlen hivatali, szellemi kapcsolattartáshoz és elég távol a közvetlen összeépülés veszélyétöl. A szakemberek könnyen kijárhatnak a tartomány fövárosából, de a dolgozók jelentős része feltehetöen a környezö kisebb települések lakóiból kerül majd ki.

$\mathrm{Az}$ elöközművesítésre kijelölt terület közlekedésföldrajzi helyzete kiváló, mellette megy el a Kelet-Nyugat (2-es) autópálya, amely Berlint és Hannovert köti össze, valamint 
az épülö Észak-Dél autópálya, amely Hamburg-Magdeburg-Halle-Lipcse-Drezda városokat kapcsolja össze. További autóutak és alsóbbrendủ utak is vezetnek a térséghez. Magdeburg jelentős vasúti csomópont, így a kijelölt térség mellett, illetve rajta keresztül vezetnek a vasútvonalak. Ugyancsak a térség mellett húzódik a Rajna-Elba-csatorna és a közelben folyik az Elba is. Ebben a helyzetben a „zöldmezős” telepítés más tartalmat takar, mint ahogy Magyarországon az a köztudatban él.

A kiválasztott terület építésre alkalmas, nagyjából sík, az épületeknél nagyobb földmunkákra nincs szükség, ugyanakkor a terület a mezögazdaság számára nem igazán értékes.

A technológiai park funkciók szerint három részre tagolható.

a) Legföbb funkciója a nagy innováció igényü ipari tevékenységek letelepítése. Két nagyobb gyár - egy gyógyszergyár és egy csomagolástechnikai üzem - már müködik. Ezeket Magdeburgból környezetvédelmi és városrendezési okokból telepitették ki, de múszaki színvonaluk (innovatív jellegük) olyan volt, amit a park vezetése megfelelőnek ítélt a befogadásra. Számos más gyár letelepítésének elökészitése van folyamatban.

A tervezök elképzelései szerint az ipari területen föleg a kis- és középüzemek múködését kívánják elösegíteni. Különösen fontosnak tartják az elektronikai ipar, ezen belül az inkubátorházban kifejlesztett gyártmányok meghonosítását. Nemzetközi tapasztalatok szerint egy ilyen nagyméretủ iparterület teljes betelepítése 15-20 évet igényel. A beruházók a jelenlegi igényekből-érdeklődésböl úgy itélik meg, hogy a szokásosnál lényegesen gyorsabban felhasználásra kerülhet az elökészített iparterület.

b) A technológiai park céljai közé tartozik továbbá, hogy a termelötevékenység és a lakosság részére szolgáltatásokat biztosítson. A fizikai és szellemi értéktermelő tevékenységeket egyaránt segíteni kívánják. Lényeges azonban, hogy a kis- és nagykereskedelmet, az idegenforgalommal kapcsolatos vendéglátást, szállodákat, a városból kiszoruló irodaházakat, ügynökségeket - amelyek részéröl élénk érdeklỏdés nyilvánult meg - nem kívánják a parkba beengedni. Ugyanakkor az odatelepült ipari üzemek, irodák stb. részére szükséges szolgáltatásokat a területen belül természetesen biztosítják. A kevésbé innovatív tevékenységek távol tartásával is hangsúlyozni kívánják a technológiai park innovációt elösegitỏ célkitủzését. A kialakított helyiségekben tanfolyamok, elóadások, konferenciák rendezhetők. A magdeburgi felsőoktatási intézmények és kutatóintézetek kihelyezett kurzusok tartását tervezik.

c) A technológiai park harmadik, de számunkra talán leginkább figyelemre méltónak tartható eleme az inkubátorház, amely mindenekelött az innovációt hivatott szolgálni. Az elkészült modern, háromszintes számitástechnikai berendezésekkel felszerelt épület teremti meg a feltételeket ahhoz, hogy a kreatív gondolkodású, vállalkozó kedvü, föként fiatal müszaki értelmiségiek ơtleteiket szabadalommá, találmánnyá érleljék és azt azután értékesítsék. Az inkubátorház feladata tehát a műszaki újdonságok létrehozásának és a termelésbe való bevitelének előkészítése, elősegítése. Az előzőnél nem kisebb jelentőségú feladata az is, hogy az itt született találmányokon keresztül támogassa, gyorsítsa az új tőkés vállalkozói réteg kialakulását. 
Az épületet a kísérletezés, müszaki fejlesztés számára megfelelően alakították ki, beleértve a szükséges infrastruktúrát. A helyiségeket rendkívül kedvező feltételekkel, a piaci ár törtrészéért adják bérbe ötéves időtartamra olyan igénylőknek, akik már eredményt tudnak felmutatni, de eszköz- és tökehiány miatt megkezdett fejlesztéseiket nem tudnák továbbvinni. A kedvezményadás legföbb célja, hogy öt év alatt gyártásra érett, versenyképes termék szülessen.

A bérlöknek a kedvezményes ötéves idó eltelte után el kell hagyniuk az inkubátorházat, illetve már csak magasabb, a normális piaci viszonyok szerinti bérleti díj ellenében maradhatnak ott tovább.

Az inkubátorházban alakították ki az egész technológiai park beruházásával és felhasználásával foglalkozó szervezet megfeleló müködési feltételeit.

A rendelkezésre álló helyiségekben a tényleges fejlesztỏ, termelő munka megkezdődött. Az inkubátorház iránt rendkívül nagy a kereslet. Hamarosan megkezdik az újabb ház építését, amelyhez a központi támogatás biztosítottnak látszik. Az elsỏ épület beruházási költsége 34 millió DM volt.

Az egész technológiai parkot a korszerü környezeti kultúra igényei, a környezetvédelmi követelmények messzemenö figyelembevételével tervezték. Az összes területnek mintegy $30 \%$-át parkosítják. Az utak mellé máris sok fát uultettek. A területen átfolyó kis patakot nem tüntették el, nem fedik be, hanem a zöldterület alakításánál adottságként kezelik.

A viszonylag részletesen bemutatott ostfaleni technológiai park méreteit tekintve kiemelkedő jelentöségú, de nem az egyetlen ilyen jellegủ fejlesztés Németország keleti részén. Számos kisebb város, nagyobb falu határában látható a mezöbe kihelyezett nagy tábla, amelyen az iparterület elökészítésének föbb adatai olvashatók, és láthatók a területelökészítést végző földmunkagépek, az építkezések kontúrjai, illetve az elkészültt üzemek, épületek.

\section{Speciális szolgáltató park}

Az ipari, technológiai parkok mellett Wismar határában találkoztunk egy a közeli múltban létrehozott speciális kereskedelmi-szolgáltató parkkal is. A tervszerúen kialakított területen hat-nyolc autógyártó világcégnek van önálló márkaszervize, telephelye. Ezek mindegyike foglalkozik új és használt autók eladásával és vételével, az eladott autók szervizelésével, javításával, alkatrészek eladásával. A kialakított bázison van nagykereskedelmi raktár, üzemanyagtöltő állomás, valamint szálloda és étterem. 


\section{Irodaváros}

Hamburg északi városrészében az 1960-as évek óta folyamatosan alakítottak ki egy városrésznek tekinthetö irodacentrumot. Az irodacentrum kiépítésével több feladatot kívántak egyszerre, tervszerủen megoldani. Hamburgnak ez a része viszonylag közel fekszik a hagyományos centrumhoz, de kiépítettsége laza és alacsony színvonalú volt. Kézenfekvönek tủnt, hogy a nagyobb, a belvárosban már ott lévő vállalatok alacsony színvonalú és sok helyen szétszórt irodáit egy helyen, korszerủ irodaházakban helyezzék el. A városba újonnan betelepülni szándékozó világcégeknek a régi belvárosban nem, vagy csak nagy nehézségek árán, sok bontással lehetett volna helyet biztosítani. A belsö városrészek megközelítési nehézségei, a korszerüségi követelmények is indokolták az irodaközpont létesítését.

$\mathrm{Az}$ új Északi Irodacentrum területét a város jelölte ki és a város építette ki a közmüveket, szabta meg a beépítési feltételeket, de az egyes házakat általában az azokat használó cégek építették meg saját igényeik, ízlésük szerint. Az idők folyamán egyes cégek irodaigényüket csökkentették, az így megüresedett helyeket már ők adják bérbe más cégeknek. Jellemzője még az új városrésznek, hogy az irodaközpontban sok a számítástechnikával foglalkozó vállalat. Ez azzal magyarázható, hogy a tevékenység az utóbbi évtizedekben fejlödött rohamosan, az érintett cégeknek most jelentkezett irodaigénye, ugyanakkor a már idetelepedett irodaházak számítástechnikai igényeinek kielégítése jelentös piacot, helyzeti elönyt is hozott számukra.

\section{Bevásárlóközpontok}

Németország keleti részén, a volt NDK területén a korábbi időszakhoz képest talán az egyik legszembetủnőbb változás a városok külsỏ részén, a beépített részektől néhány kilométerre felépített és napjainkban is épülö bevásárlóközpontok. A magyar lakosság számára a bevásárlóközpontok a korábbi ausztriai és az újabb hazai példák alapján már nem ismeretlenek. A németországi tapasztalatok mégis lenyủgözőek, mindenekelött a méretek, a színvonal és sokrétüség révén. A bevásárlóközpontok egészen újak, szinte érezni a mész és festék szagot. Úton-útfélen látni az újabb és még nagyobb építkezéseket. Ebből látszik, hogy az átlagpolgár napi és rendszeres szükségleteit mindinkább ebböl a kereskedelmi formából elégíti ki. A nagyobb bevásárlóközpontokban szinte minden megtalálható a kerti szerszámoktól a számológépig, a gyerekjátéktól a kutyaeledelek széles választékáig. Vendéglők, játszóterek, szőkőkút és még számos szükséges és kevésbé fontos létesítmény, szolgáltatás szolgálja a vevók igényeit, gazdagítja az eladókat. Minden bevásárlóközponthoz nagy gépkocsi parkoló tartozik. Ezekben minden időben van szabad hely személygépkocsik, teherautók, autóbuszok számára egyaránt. A bevásárló- 
központok környékét általában parkosították, azokat szépen gondozzák. A bevásárlóközpontok kiépülésének következménye a belvárosi üzletek megszünése, illetve profilváltása.

A hagyományos városi bolti eladás és az új, a települések külső területein kialakult és gyorsan bövülö kereskedés között lényeges a különbség. A centrumok boltjaira a specializáltság a jellemzö, viszonylag szük sávban, de nagy választékban kínálják portékáikat. Ezeknek az üzleteknek a színvonala igen különböző attól fưggően, hogy a város melyik részében helyezkednek el. A belvárosi boltok nagyon elegánsak, exkluzív választékkal és magas árral dolgoznak. A nagyobb városok központjában a bankok, az irodák, az üzletek mindinkább kiszorítják a lakásokat, a lakók nem tudják megfizetni a magasra kúszó bérleti dijakat.

A németországi városok érdekes szinfoltját nyújtják, különösen a régi városok belvárosainak föterén ma is müködő piacok. Ezekben a városokban a piacok müködését, a zöldség-, a gyümölcs-, a virágárusítást, fagylaltozók üzemeltetését nem tartják a városképet rontónak vagy környezetszennyezönek. A piaci nyüzsgés nem zavarja sem a forgalmat, sem a városok életét, azt természetes adottságnak fogják fel. Az igazsághoz azonban az is hozzátartozik, hogy a piaci időszak vége után néhány perccel a tér kiürül és sem szemét, sem eldobott csomagoló anyagok nem láthatók. Zárás után negyedórával a piacnak nyoma sincs, a délutáni sétálóké a tiszta tér.

Talán érdemes megemlíteni mi az amivel nem vagy alig lehet találkozni Németországban a kereskedelemben, a városok hétköznapjaiban.

Az utcákon, tereken, aluljárókban, pályaudvarokon és általában a közterületeken a kézböl, a földről vagy kis asztalkákról való eladási móddal nem találkoztam.

Az utcai bódékban, kapualjakban - a nálunk dívó - mini bóvli-boltokkal csak ritkán lehet látni.

A kínai vagy más ázsiai nemzetek boltjai is kuriózumnak számítanak és nem olcsó ruházati termékeket árusítanak, hanem jellegzetes népi-nemzeti karakterü, föként ajándéktárgyakat.

A használt ruhákat árusító boltok ugyancsak ritkák, a nagyobb városokban egy-egy ha akad belölük. A hivatalos, normális piacok mellett a másodlagos - lengyel, KGST-piac nem ismeretes.

\section{Városépités}

A két hét folyamán monumentális épitkezéssel nem találkoztam, csupán néhány kisebb lakótelep építését láttam. A családiházas építés sem gyakori látvány, ugyanakkor a belvárosi házak renoválása, felújitása, egyes régi házak teljes megújítása általánosnak látszik. Az elmúlt évtizedekben az NDK-ban épített lakótelepek tatarozása, megfiatalítása megkezdődött.

A régi házak, az ősi városok utcái, központi terei eredeti arculatának megőrzésére való törekvés több városban jelen van. Előfordul, hogy a régi épületböl csak az utcai 
homlokzatot örzik meg eredetiben és mögé a régi épület alaprajzát és kontúrját megtartva teljesen új, korszerủ anyagokból a jelenlegi igényeknek megfelelỏ modern lakásokat, üzlethelyiségeket és más rendeltetésủ tereket alakítanak ki.

\section{Általánositható területfejlesztési tapasztalatok}

A német egység megteremtése után a keleti országrészben a földek nagyrészt magántulajdonba kerültek. A látottak azt tükrözik, hogy a föld ára nem lehet túlzottan magas, mert nagy elöszeretettel építkeznek. Az újonnan közmúvesített területeken a kereskedelemben gyakori tömbösített épületegyüttesek kialakítása ellenére nem bánnak nagyon takarékosan a területekkel, illetve úgy is megközelíthetjük a kérdést, hogy környezetbarát módon építkeznek. Az egyes épületek között tágas, parkositott területek találhatók.

Németország és más fejlett piacgazdaságú országok gyakorlatából mindinkább általánosnak tünő tendencia, hogy az iparban, kereskedelemben, az idegenforgalomban, a szolgáltató ágazatokban, valamint az irodaházak és a lakások építésénél a beruházások telepszerủ elhelyezése előré elkészített közmüvesített területeken történik. Az egyes vállalkozások, családok elhelyezéséhez szükséges létesítményeket a településrendezési terveknek megfelelően gondosan megtervezett és komplexen elökészített területeken valósítják meg.

A területek előközmủvesítését, a beruházások fogadására való felkészitését általában a központi és területi-helyi szervek egyaránt támogatják és ösztönzik. Ez a fejlesztési mód a beruházók számára a kivitelezési idő rövidítését, a fajlagos költségek lényeges csökkenését, a helyben kialakítható termelési és egyéb kapcsolatok kiépítésének kedvezö lehetőségeit segíti elö. Az előközmủvesítés fogadásához általában a települések határán kívül jelölnek ki megfelelő területet, de a régi, elavult, leromlott városrészek megújitásánál is alkalmazzák ezt a módszert, például Londonban az elöregedett dokknegyed megújítása iroda-üzlet centrum létrehozásával történt.

Úgy látszik, hogy a tervszerú területelökészítés és a tevékenységek szerinti csoportos telepítések a területfejlesztés lényeges elemévé és ezek megvalósitása mindinkább terebélyesedö üzletággá válik. A módszer előnyeit Magyarországon és a környező országokban már évtizedek óta felismerték, korlátozott körben alkalmazták is. Szélesebb körủ elterjedését a beruházási költségek megelölegezéséhez szükséges jelentös tőke hiánya, valamint az esetleges megtérülési kockázat nehezíti. A válságtérségek tervszerü ipari és más irányú fejlesztésének az előközművesítés, ipari, kereskedelmi stb. parkok létesítése lényeges és hatékony eszköze lehetne hazánkban a következö években. A rendelkezésre álló képzett, de munkanélküli munkaerő, a kiépített részlegesen meglévô infrastruktúra lehetővé és szükségessé teszi a gazdasági megújulás ilyen irányá keresését. 


\section{Irodalom}

Bartke I. (1971) Az iparilag elmaradott területek ipari fejlesztésének föbb közgazdasági kérdései Magyarországon. Akadémiai Kiadó, Budapest.

Benko, G. (1992) Technológiai parkok és technopolisok földrajza. MTA Regionális Kutatások Kơzpontja, Pécs.

Eine Wirtschaftsregion gewinnt neues Profil. Nationales Sonderprogramm für den Raum Halle (Bitterfeld) Merseburg. Land Sachsen-Anhalt Staatskanzlei Presse- und Informationsamt, Magdeburg, 1993.

Grause, G.-Grundmann, L. (1994) Funktion und Struktur im Wandel - der Nordwesten der Stadtregion Leipzig. Europa Regional, 2. 10-22. o.

Möller, I. (1985) Hamburg. Ernst Klett Verlag, Stuttgart.

Tatai Z. (1971) Mátészalka ipari fejlödése. Szabolcs-Szatmári Szemle, 2. 1-18. o.

Tatai Z. (1984) Iparunk területi szerkezetének álalakitása. Kossuth Könyvkiadó, Budapest.

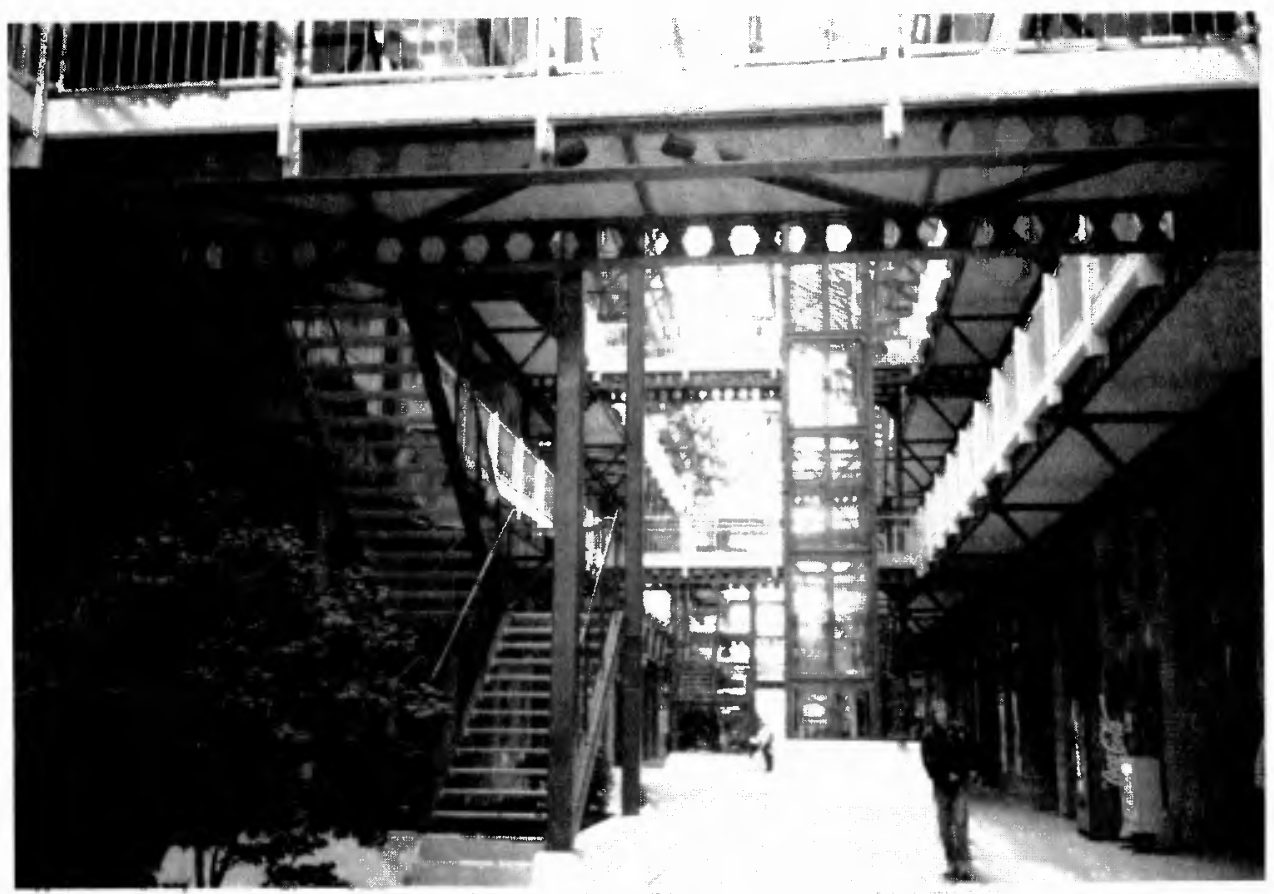

A TPO inkubátorházának belsỏ képe (Tatai Zoltán) 
Tér és Társadalom 8. évf. 1994/3-4. 100. p.

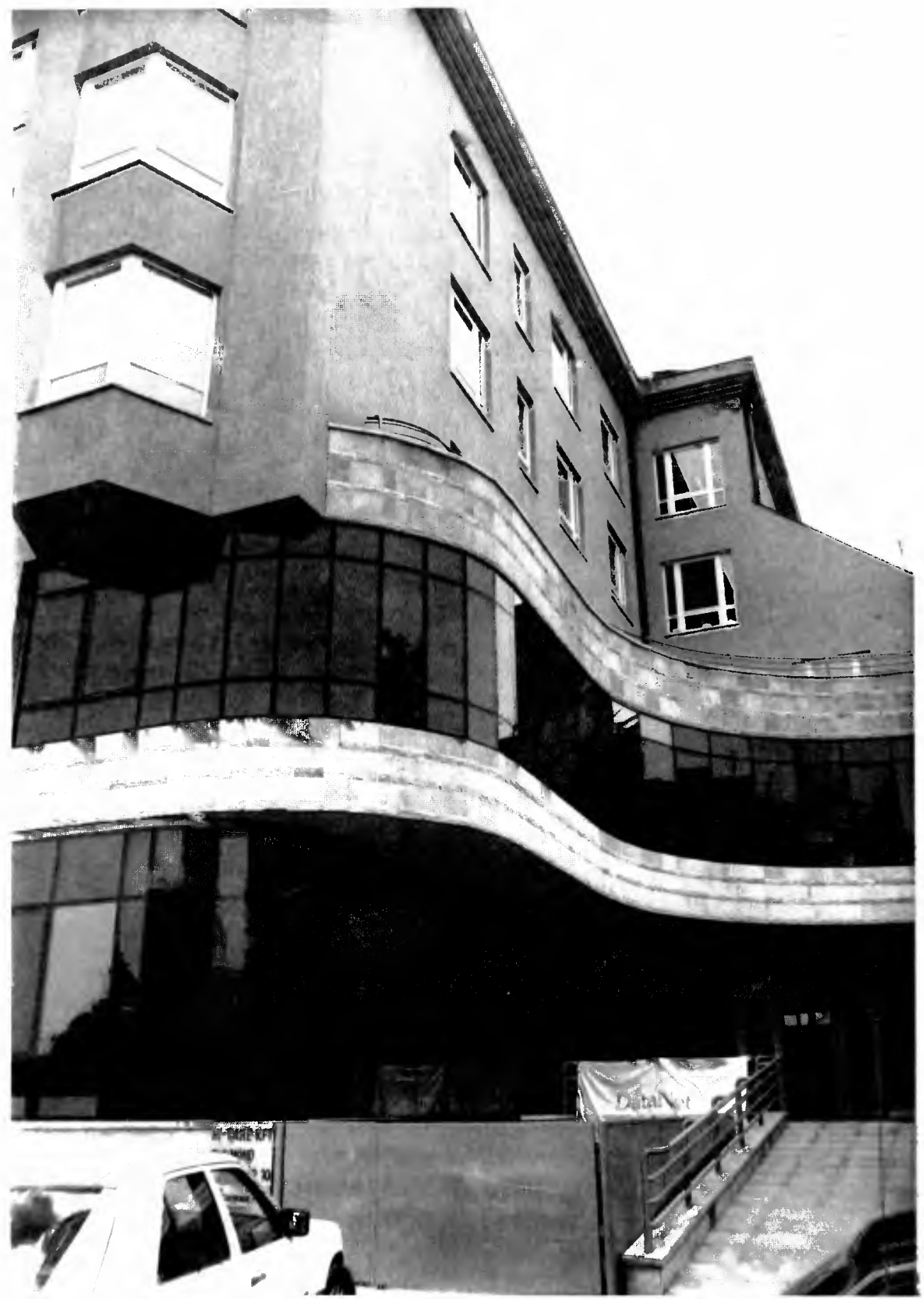

Új információs adatszolgáltatási központ Budapesten (MTI FOTÓ - Balaton József) 